\author{
URSZULA OSZWA \\ Maria Curie-Skłodowska University in Lublin, Poland \\ ORCID: https://orcid.org/0000-0002-0300-909X \\ urszula.oszwa@mail.umcs.pl
}

\title{
Report on the Second National Problem-Methodical Conference in the series: "Let Children Think". Topic: "Logical Thinking in the Service of (Not Only) Mathematics", Opole, 22 April 2021
}

The Conference was organized by the Regional Centre for Education Development [Regionalne Centrum Rozwoju Edukacji] and the Regional Team of Educational Support Institutions [Regionalny Zespót Placówek Wsparcia Edukacji, RZPWE] in Opole. It had a problem-methodical character and was addressed to teachers and consultants of mathematics education in Poland. Due to the sanitary regime associated with the COVID-19 pandemic, the Conference was held remotely via the MS Teams platform.

After the ceremonial opening of the Conference by the local authorities and a short welcome by the president of the RZPWE and the Opole education welfare officer, the inaugural lecture was delivered by Ms Hanna Franczak, vice-president of the RZPWE in Opole. The lecture was an introduction to the conference theme and was entitled: "When Stress Destroys Memory - Reflections on the Learning Process".

The plenary part included two scientific lectures. Habilitated doctor Jolanta Karbowniczek, Professor at the Ignatianum Academy in Cracow, presented a complex issue of multi-paradigm in early education of a child as the essence of reflection on teaching learning. Habilitated doctor Małgorzata Żytko, Professor at the University of Warsaw, led the audience through the meanders of reflections on the primacy of 
mathematics education in the process of discovering and experimenting instead of reproducing and acquiring the so-called transmission knowledge. The contrasting juxtaposition of constructivism and behaviourism in education has been the subject of theoretical discussions for years, which have been very slowly followed by the practice of mathematics education. The lecture was a particularly valuable inspiration for practitioner educators attending the Conference.

After the break, the session began, showing the implication value of research results and experiences in educational practice. This session included three presentations. Doctor Renata Reclik from the University of Opole introduced the participants to the issues of shaping and developing mathematical skills at the early education level. Two further presentations were devoted to creativity and innovation as key competences in contemporary education, not only in mathematics. Teresa Kosiarek, an experienced educator from the Academy of Creative Teachers in Otwock, presented the issue of creativity in education in a speech entitled "It Is Worthwhile to Be Unconventional Shaping the Pro-Innovative Attitudes of the Contemporary Generation of Children". A teacher from DIDASKO Private Elementary School No. 98 in Warsaw, Ms Beata Ordakowska, presented the topic: "How to Develop Children's Creative and Logical Thinking Skills on a Daily Basis?" The session provoked many questions from the participants, which started an interactive discussion on the different possibilities and necessity of developing logical thinking, a leading theme of the Conference.

The next part of the event was a workshop and took place in four virtual rooms in parallel. It lasted 45 minutes. After a short break, the presenters repeated their workshops once more, which gave the opportunity for every Conference participant to attend two of them.

Ms Marzena Kędra led a workshop entitled "How to Make a Child Want to Learn". Ms Teresa Kosiarek presented in a practical way the issue of training the ability to break schemes. The workshop was entitled "Contemporary Education with(out) Schemas - Strategies in Breaking Down Blockages in Children's Thinking, Acting and Finding Solutions". In her workshop, Ms Alicja Jadach addressed the issue of motivation and engagement of students in learning mathematics. She entitled her workshop "Upside Down Mathematics. How to Motivate and Engage Students in Learning Mathematics". Ms Krystyna Dąbek also pursued the motivational theme in her workshop which was entitled: "Mathematics Stop. To Get In or to Get Out?"

The intensive interactive part of the workshop was followed by a short break. The substantive part of the Conference ended with a lecture by habilitated doctor Urszula Oszwa, Professor at the UMCS in Lublin, who presented the issue of the fear of mathematics from a psychopedagogical perspective. Based on the results of the study, she showed the symptoms and effects of fear of mathematics at the neurological, behavioural, cognitive and social levels. She also presented the mechanisms of how fear of mathematics affects mathematical achievement and logical thinking. She concluded 
her lecture by presenting a psychosocial model for alleviating fear of mathematics, noting the special role of the inspirational teacher in this process.

The summary of the Conference and the announcement of the results of the most interesting scenario of classes entitled "My Student Thinks Logically", was made by Anna Patelska-Górna, the manager of the Laboratory of General Education Didactics and Information Technology [Pracownia Dydaktyki Kształcenia Ogólnego i Technologii Informatycznych] at the RZPWE in Opole. The theme for the next conference of the series, planned for 2022, was announced. It will be devoted to the problem of learning difficulties in mathematics at different stages of education.

Participants expressed their gratitude to the speakers for the inspiring content and to the organizers for a successful event in numerous postings on the meeting forum immediately after each speech and after the Conference. 